\title{
INNOWACYJNOŚĆ POLSKICH PRZEDSIĘBIORSTW NA TLE EUROPEJSKICH SYSTEMÓW INNOWACYJNOŚCI
}

DOI: $10.33141 /$ po. 2020.09.03

\section{Jerzy Różański}

\section{Wprowadzenie}

nnowacyjność gospodarek poszczególnych krajów Unii Europejskiej (i krajów stowarzyszonych - jak Norwegia, Islandia czy Szwajcaria) jest bardzo zróżnicowana. Największą innowacyjność wykazują państwa skandynawskie, Niemcy czy Wielka Brytania, najniższy - większość nowych członków Unii Europejskiej - w tym Polska. Istotne jest więc określenie przyczyn, dla których jedne państwa osiągnęły wysoki poziom innowacyjności, a inne - i tu głównie chodzi o Polskę, nie zdołały nawet osiągnąć średniego europejskiego poziomu.

Celem artykułu jest, w oparciu o dostępną literaturę i badania własne, próba odpowiedzi na dwa pytania badawcze:

- jakie są przyczyny osiągnięcia wysokiego poziomu innowacyjności przez niektóre kraje europejskie, a gorszego przez inne (m.in. Polska)?

- jakie działania pozwoliłyby osiągnąć polskim przedsiębiorstwom i gospodarce, jako całości, wyższą innowacyjność, a przez to i wyższą konkurencyjność na światowych rynkach?

Autor stawia tezę, że skuteczne działania wielu krajów w sferze innowacji (np. Wielka Brytania, Niemcy) mogą stanowić wzorzec dla innych, w tym i Polski.

Przyjęto następującą strukturę artykułu:

- określenie miejsca Polski w rankingu innowacyjności UE w ujęciu dynamicznym;

- wskazanie wyników przeglądu literatury istotnej dla treści artykułu;

- przedstawienie wyników własnych badań empirycznych;

- syntetyczne porównania czynników wpływających na innowacyjność Wielkiej Brytanii, Niemiec i Hiszpanii;

- wnioski końcowe autora.

\section{Miejsce gospodarki polskiej z punktu widzenia jej innowacyjności na tle innych krajów Unii Europejskiej}

D la oceny miejsca Polski w UE jako kraju, który ma za zadanie zwiększać swoją innowacyjność, przyjęto kilka wskaźników, w UE uznawanych za istotne z punktu widzenia oceny innowacyjności państw - członków UE.

Spośród 9 czynników wymienionych przez Innovation European Scoreboard wybrano cztery uznawane za najważniejsze (Różański, Voytovych, 2019, s. 177):

- wydatki na działalność badawczo-rozwojową (relacjonowane w stosunku do produktu globalnego brutto);
Przegląd Organizacji, Nr 9(968), 2020, s. 19-26

www.przegladorganizacji.pl

(c) Towarzystwo Naukowe Organizacji i Kierownictwa (TNOiK)

- wydatki na działalność innowacyjną, niezaliczane do działalności badawczo-rozwojowej (w relacji do PKB);

- udział innowacyjnych małych i średnich przedsiębiorstw współpracujących $\mathrm{z}$ innymi podmiotami w ogólnej liczbie innowacyjnych przedsiębiorstw;

- eksport produktów o średnim i wysokim poziomie technologii do eksportu ogółem danego kraju.

W celu uchwycenia występujących w obecnym dziesięcioleciu trendów, biorąc za punkt wyjścia kształtowanie się wcześniej wskazanych czterech wskaźników, wyliczono dla lat 2011-2019 wielkości tych wskaźników i linie trendu:

- dla kraju, w którym konkretny wskaźnik kształtował się najbardziej korzystnie (analiza dotyczy nie tylko krajów UE, ale również stowarzyszonych);

- średnią dla UE;

- wartość wskaźnika dla Polski;

- wartość wskaźnika dla krajów UE, w których dany wskaźnik kształtował się najmniej korzystnie (również kraje stowarzyszone).

Linia ciągła przedstawia wartości dla poszczególnych lat, linia przerywana jest wyliczoną linią trendu dla tego okresu.

Wskaźnik wydatków na sferę badawczo-rozwojową (w relacji do PKB) najkorzystniej kształtował się w Szwecji, znacznie powyżej średniej dla UE. Mimo pewnych wahań, w całym analizowanym okresie, zarówno dla Szwecji, jak i dla UE, w poszczególnych latach wskaźniki utrzymały się na zbliżonym poziomie. Wskaźnik dla Polski, zdecydowanie niższy, wykazuje jednak wyraźną w latach 2011-2019 tendencję rosnącą. Najsłabszym krajem jest tutaj Cypr, w którym wydatki na sferę B+R utrzymują się na stabilnym, bardzo niskim poziomie, ale również wykazując niewielki wzrost.

Zupełnie inaczej kształtowały się wydatki na innowacje poza sferą badawczo-rozwojową (rys. 2). Tutaj krajem, w którym wydatki te rosły najszybciej w latach 2011-2019, była Szwajcaria (szczególnie szybki przyrost w latach 2013-2015), która w Europie jest liderem, jeśli chodzi o ten rodzaj wydatków na innowacje. Wskaźnik dla Polski w całym analizowanym okresie jest wyraźnie wyższy niż dla UE i najsłabszego tu Luxemburga. Wysoka pozycja Polski w okresie 2011-2019 wynika stąd, że pozyskuje innowacje z zewnątrz, czego nie należy uważać za działanie nieracjonalne, ponieważ jest to sposób pozyskiwania innowacji przy słabiej rozwiniętej sferze B+R. Warto zauważyć, że poziom wydatków w tej sferze, zarówno w Polsce, jak i w UE jest dość stabilny. 
Wskaźnik obrazujący udział innowacyjnych małych i średnich przedsiębiorstw współpracujących z innymi podmiotami w ogólnej liczbie przedsiębiorstw innowacyjnych, a więc udział przedsiębiorstw tworzących sieci współpracy z innymi przedsiębiorstwami, jest dla Polski bardzo niekorzystny (rys. 3). Najlepsze rezultaty w analizowanym okresie osiągnęła Wielka Brytania (przy wyraźnym trendzie rosnącym w latach 2016-2019), znacznie niżej ten wskaźnik (i dość stabilnie) kształtuje się w krajach UE jako średnia), natomiast Polska ma wyniki zbliżone do najsłabszej tu Rumunii (w dodatku w obu przypadkach mamy do czynienia jeszcze $\mathrm{z}$ nieznacznym spadkiem tego wskaźnika).

Ze względu na brak danych za lata 2011-2014 wskaźnik udziału eksportu o średniej i wysokiej technologii dla eksportu ogółem został wyliczony dla lat 2015-2019 (rys. 4). Jak się okazuje, wskaźnik ten w latach 2015-2019 najkorzystniej kształtował się dla Węgier, przekraczając dość znacznie średni wskaźnik dla UE ogółem. Najszybszy wzrost tego wskaźnika notuje jednak Unia Europejska jako całość. Polska ma ten wskaźnik dość stabilny w tych latach, nieco niższy niż średnia unijna. Bardzo słabo wskaźnik ten kształtuje się w przypadku Islandii, wykazując tu jednocześnie tendencję spadkową.
Przedstawiona analiza, oparta na czterech wybranych wskaźnikach, uznanych przez autora za najważniejsze, pokazuje, że w analizowanym okresie istnieje daleko idąca stabilność, jeśli chodzi o poziom tych wskaźników.

Uwzględniając również inne wskaźniki opracowane w ramach metodologii European Innovation Scoreboard, którą bierze się pod uwagę przy ocenie innowacyjności gospodarek określonych krajów (patenty, sprzedaż nowości, eksport usług), Polska lokuje się jednak w grupie krajów najsłabszych (85 punktów przy 225 punktach uzyskanych przez Niemcy i Szwajcarię w 2015 roku). Najgorzej wypadają Bułgaria (48 pkt.) i Rumunia (55 pkt.). Mimo więc uzyskiwania dość dobrych rezultatów w nakładach na innowacje poza sferą $\mathrm{B}+\mathrm{R}$ i w eksporcie średnio i wysoko zaawansowanych technologicznie produktów, pozycja Polski, biorąc pod uwagę innowacyjność jej gospodarki, jest ciągle niska (dane European Innovation Scoreboard - za dany okres).

Porównując innowacyjność już nie gospodarki Polski jako całości, ale poszczególnych jej sektorów do innowacyjności tych sektorów w innych krajach, otrzymujemy również wyniki niekorzystne dla Polski. I tak np. J. Swacha (2016, s. 37-45) stwierdza, że „polski sektor IT w niemal wszystkich rozpatrywanych aspektach technologicznych,

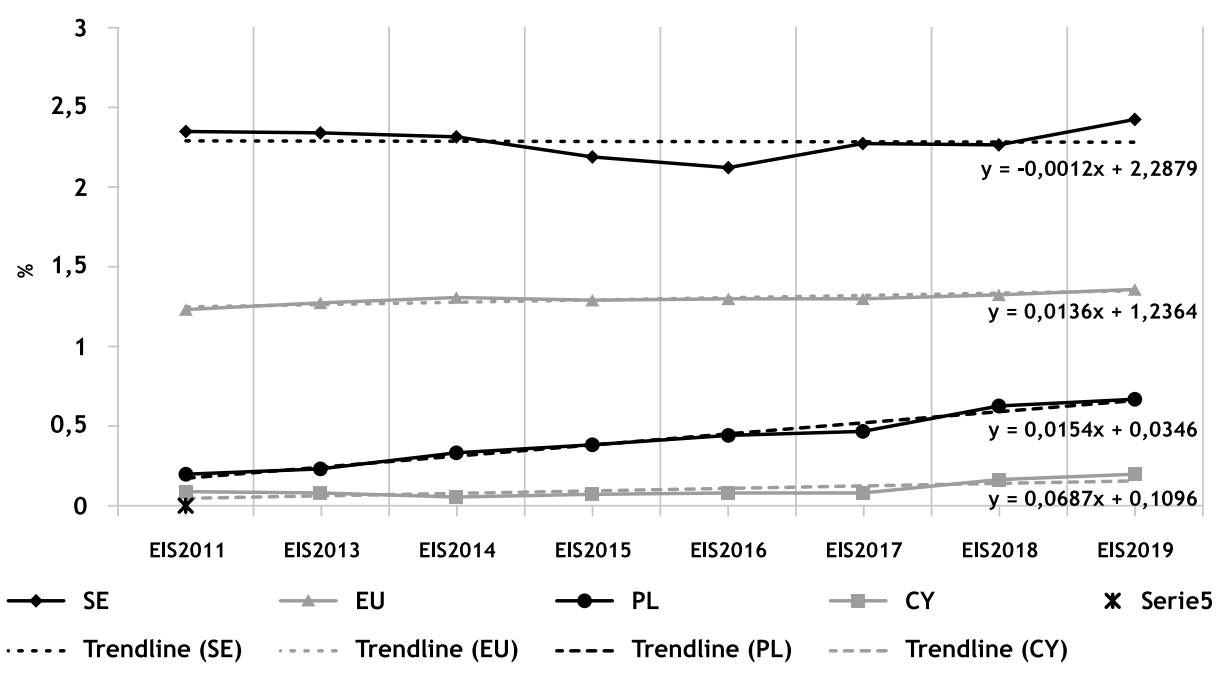

Rys. 1. Wydatki na sferę badawczo-rozwojową w sferze biznesu - linia trendu Źródto: opracowanie wtasne na podstawie danych European Innovation Scoreboard 2011-2019

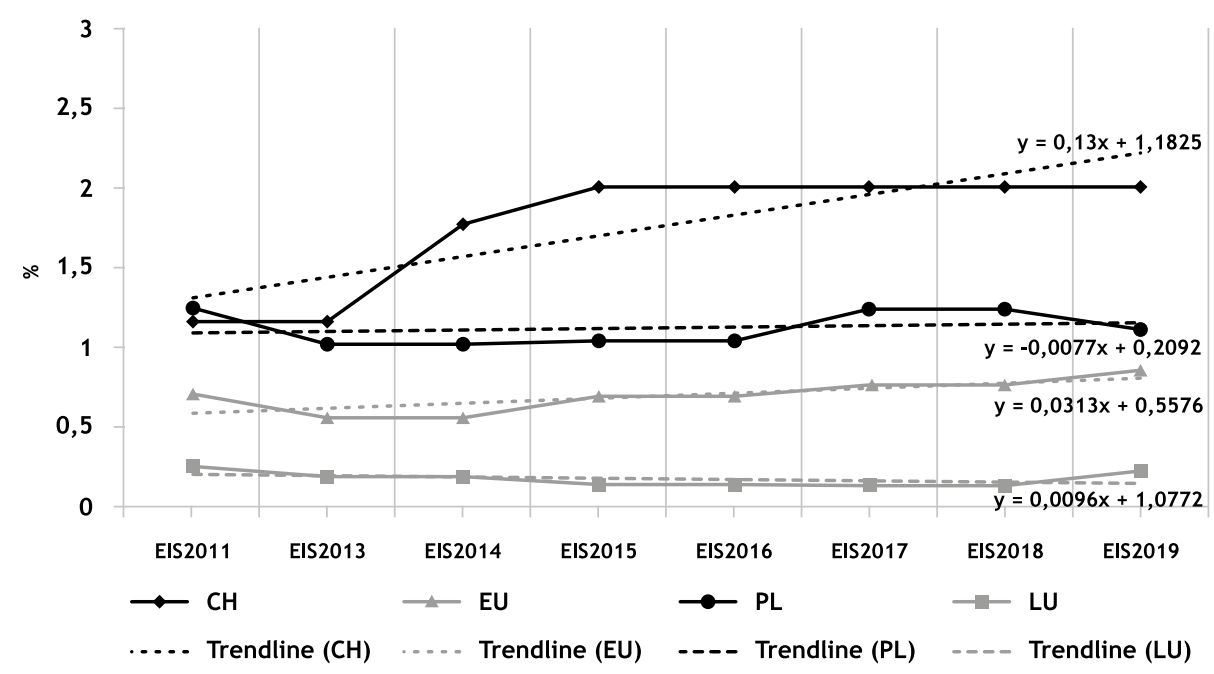

Rys. 2. Wydatki na innowacje poza sferą badawczo rozwojową - linia trendu Źródto: opracowanie wtasne na podstawie danych European Innovation Scoreboard 2011-2019 
społecznych i ekonomicznych dzieli olbrzymi dystans do liderów". Okazuje się, że w całej Unii w sektorze tym wyprzedzamy jedynie Grecję. Z kolei J. Brzóska i J. Cierkosz (2016, s. 15) próbują pokazać miejsce Polski nie tylko na tle krajów europejskich, ale również i w rankingach światowych (Global Innovation Index), gdzie Polska zajmuje najczęściej dalekie miejsca (44-49).

Jeśli więc Polska chce zapewnić sobie stabilny, długotrwały rozwój gospodarczy, musi zwiększyć swoją innowacyjność, a przez to i konkurencyjność na światowych rynkach.

\section{Przyczyny niedostatecznej innowacyjności przedsiębiorstw w Polsce}

zybki rozwój gospodarczy Polski nie może więc przesłaniać faktu, że Polska cały czas jest jeszcze krajem, który z punktu widzenia nowoczesności gospodarki, jej innowacyjności, jest krajem słabym, a nadążanie za najlepiej rozwiniętymi krajami gospodarki rynkowej będzie istotnym zadaniem dla polityki gospodarczej kraju i strategii rozwojowej pojedynczych przedsiębiorstw przez długi czas. W tej sytuacji bardzo istotne staje się pytanie o sposób, w jaki nadanie gospodarce bardziej innowacyjnego charakteru będzie miało miejsce. J. Cieślik (2014, s. 140) zwraca uwagę na to „że im wyższy w danym kraju poziom zaawansowania technologicznego, tym relatywnie niższy koszt wdrożenia kolejnych innowacji. To tłumaczy, dlaczego z efektów postępu techniczno-organizacyjnego korzystają w pierwszej kolejności kraje wysoko rozwinięte".

J. Cieślik polemizuje z poglądem, że tylko pierwotne innowacje, często przełomowe, stanowią podstawę sukcesu rynkowego przedsiębiorstwa. Powołując się na wyniki badań A. Bhide’a (2000), stwierdza, że jedynie 6\%

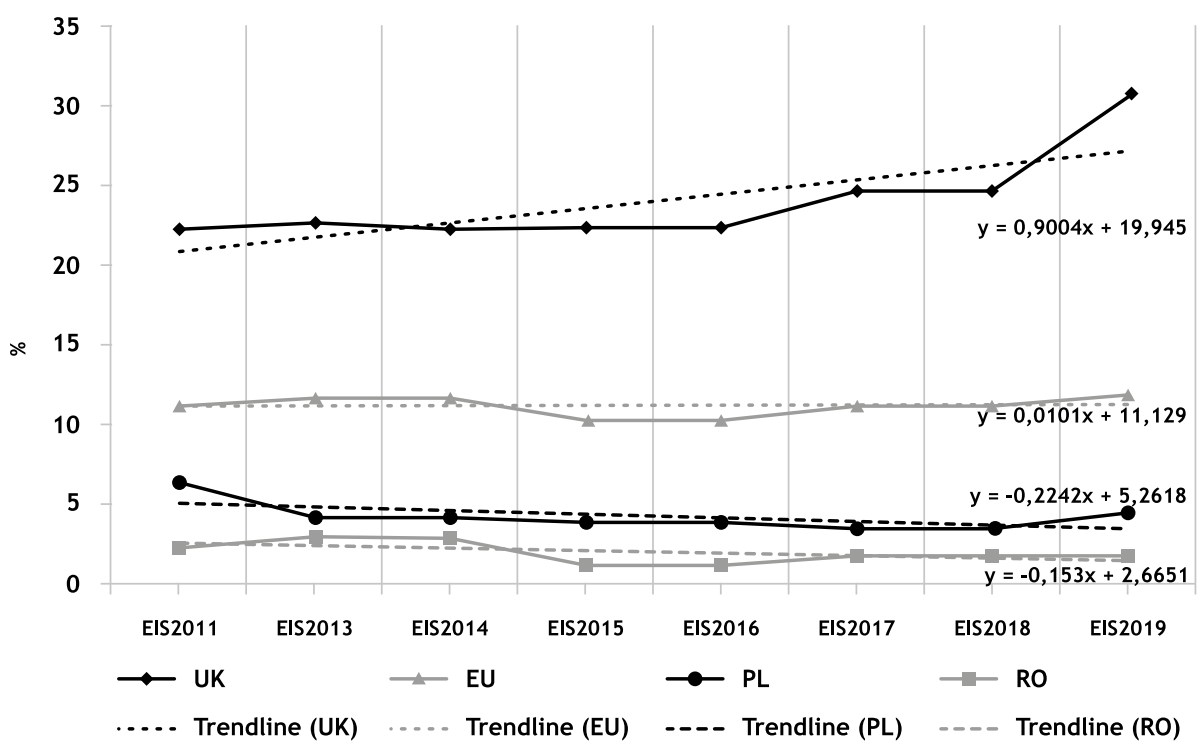

Rys. 3. Innowacyjne mate i średnie przedsiębiorstwa współpracujące $z$ innymi podmiotami - linia trendu

Źródto: opracowanie wtasne na podstawie danych European Innovation Scoreboard 2011-2019

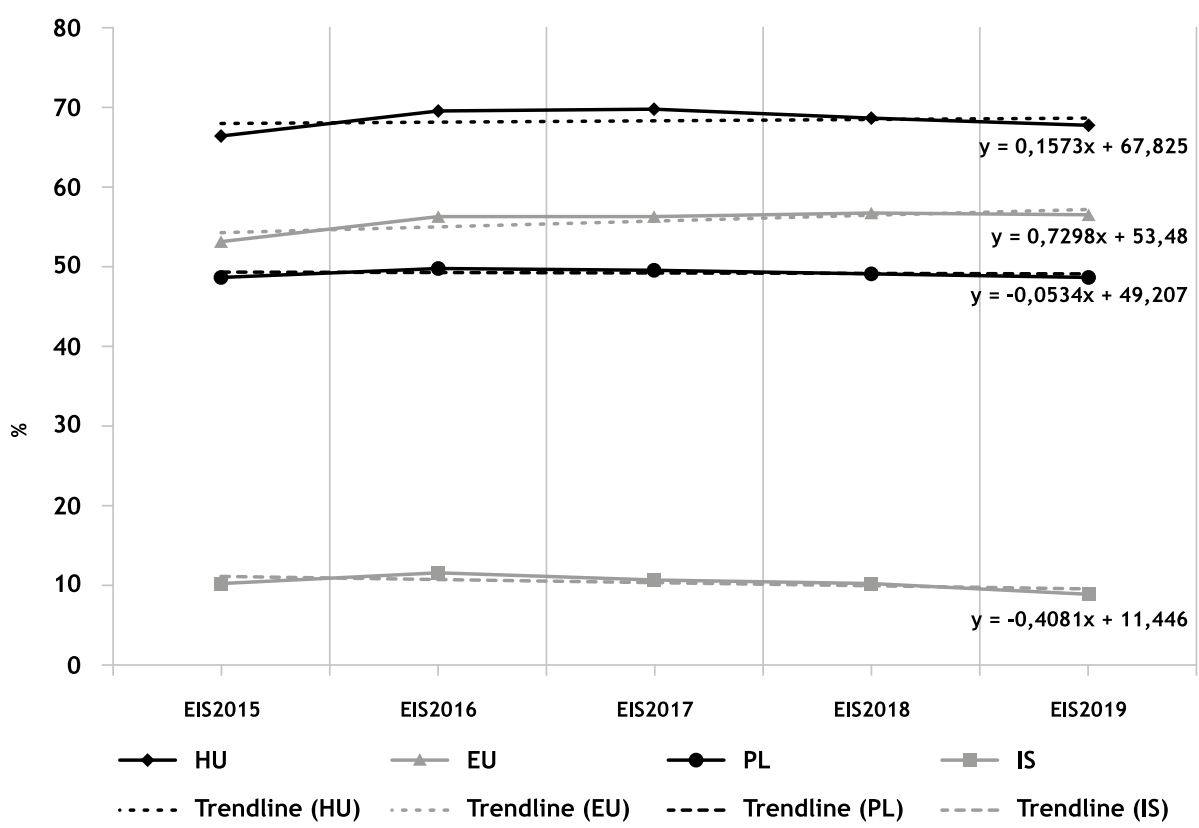

Rys. 4. Eksport produktów o średnim i wysokim zaawansowaniu technologicznym - linia trendu Źródło: opracowanie wtasne na podstawie danych European Innovation Scoreboard 2011-2019 
respondentów w tych badaniach potwierdziło, że rozpoczynało działalność, dysponując unikalnym produktem lub usługą, 58\% odnoszących sukces przedsiębiorstw oferowało substytuty identyczne lub niemal identyczne, a w 36\% wyroby lub usługi różniły się tylko funkcjonalnością lub ceną. Tak więc „pomysł na super szybki biznes polegał na imitacji lub tylko niewielkiej adaptacji wyrobów lub usług, już dostępnych na rynku" (Cieślik, 2014, s. 144).

W tej sytuacji należałoby obiektywnie ocenić znaczenie imitacji w gospodarce. Przyspieszenie rozwoju gospodarki może być osiągnięte zarówno przez innowacje pierwotne, jak i przez imitacje - często mamy do czynienia ze wzajemnym uzupełnianiem się obu dróg rozwoju produktu czy usługi. Jest to szczególnie istotne w warunkach polskiej gospodarki, której cechami charakterystycznymi są:

- słaba współpraca sfery nauki i sfery biznesu;

- słabe efekty działania jednostek otoczenia biznesu (centra transferu technologii, parki przemysłowe, inkubatory przedsiębiorczości);

- niedostatek jednostek naukowo-badawczych, zlokalizowanych przy większych przedsiębiorstwach krajowych (w początkowym okresie transformacji ustrojowej w Polsce masowo likwidowano tego typu jednostki);

- zbyt mała efektywność wsparcia procesów innowacyjnych ze szczebla centralnego lub regionalnego (Kaźmierczak, Różański, 2013, s. 147-153).

Formułowany jest też pogląd, że „efektywność mechanizmów „wytwarzających” wiedzę przydatną do rozwiązywania różnego typu problemów (technicznych, społecznych czy organizacyjnych), a także dostępność i koszt takiej wiedzy i informacji stanowią obecnie niekwestionowany warunek rozwoju przedsiębiorczości i innowacyjności” (Matuszak, 2008, s. 97). Stąd też często rozwiązania przyjęte i sprawdzone w krajach rozwiniętej gospodarki rynkowej nie okazują się dostatecznie efektywne w krajach emerging markets, w tym również i w Polsce. Stwierdza się więc, że kraje „nieposiadające odpowiedniego dynamizmu systemowego i wewnętrznego imperatywu do kreowania nowych rozwiązań jeszcze długo nie będą $\mathrm{w}$ stanie stworzyć wewnętrznych mechanizmów odpowiedzialnych za generowanie nowej wiedzy i możliwości jej implementacji” (Wiśniewska, Janasz, 2016, s. 187). Jakkolwiek można polemizować $\mathrm{z}$ tym poglądem, uznając, że w dużym stopniu innowacyjność uzależniona jest od możliwości i podejścia występującego w samych przedsiębiorstwach, to jednak nie ulega wątpliwości, że mechanizmy kreowania innowacyjności nie działają w Polsce tak, jak można by sobie tego życzyć.

Wielu autorów stwierdza, że „wydatkowanie środków unijnych $\mathrm{w}$ niewielkim stopniu przekłada się na poziom innowacyjności polskiej gospodarki” (Rosati, Wiśniewska, 2016, s. 138). Do istotnych przyczyn zalicza się tu:

- premiowanie tych, którzy szybko wydają środki finansowe, gdyż liczy się ich wydanie;

- preferowanie małych i średnich projektów o niskim ryzyku opóźnienia w realizacji;

- nieefektywność całego systemu wydatkowania środków z dużą ilością regulacji prawnych, nadmierną formalizacją i biurokracją;
- prymat spełniania wymogów formalnych oraz skuteczny lobbing grup interesów skierowany wylącznie na uzyskanie tych środków.

W rezultacie często przepadają projekty innowacyjne, ambitne o dużym potencjale rozwojowym, $\mathrm{z}$ odroczonymi $\mathrm{w}$ czasie efektami w stosunku do momentu rozpoczęcia wydatkowania środków.

To wszystko sprawia, że mimo wydatkowania dużych kwot na innowacje efekty są niedostateczne. Dodatkowo mamy perspektywę zmniejszających się wpływów z funduszy europejskich na wsparcie rozwoju gospodarki Polski, co sprawia, że $\mathrm{w}$ coraz większym stopniu innowacje będą musiały być finansowane z własnych środków państwa lub przedsiębiorstwa. W monografii pod redakcją D. Rosatiego i J. Wiśniewskiej (2016, s. 56) zwraca się uwagę na strukturalne uwarunkowania zbyt słabych efektów działalności innowacyjnej w Polsce. Większość przedsiębiorstw działających $\mathrm{w}$ Polsce to mikroprzedsiębiorstwa o niewielkim potencjale innowacyjnym. Gospodarka opiera się na przedsiębiorstwach bazujących na tanich czynnikach produkcji, w dużym (choć zmniejszającym się) stopniu na taniej pracy. Tak więc, zdaniem autorów, dopiero przebudowa struktury gospodarczej Polski da możliwość zwiększenia innowacyjności gospodarki jako całości.

Natomiast $\mathrm{w}$ samych przedsiębiorstwach proces wdrażania innowacji musi wiązać się $\mathrm{z}$ „opracowaniem strategii innowacyjnej oraz planów wdrożeń i rozwoju na podstawie analizy potencjału technologicznego przedsiębiorstwa oraz trendów rozwojowych" (Wrzalik, Kucęba, 2019, s. 27-35). Autorzy stwierdzają, że decyzję o wprowadzeniu innowacji musi poprzedzać audyt technologiczny oraz ocena zasobów i ryzyka, a po jej wprowadzeniu - ocena stopnia realizacji strategii rozwoju przedsiębiorstwa. Duże znaczenie ma przynależność sektorowa przedsiębiorstwa. Według W.M. Cohena i D.A. Levinthala (1989, s. 569-596), przedsiębiorstwa działające w sektorach charakteryzujących się wysokim poziomem inwestycji w sferze badań i rozwoju mają wyższą skłonność do współpracy z uczelniami i korzystania z wiedzy naukowej. Często podkreśla się ważną rolę współpracy przedsiębiorstw przy inicjowaniu i wdrażaniu innowacji (strategia zależna). R. Drewniak (2018, s. 159) zwraca uwagę na to, że „w przeważającej liczbie innowacje (produktowe i procesowe) zostały wdrożone przez przedsiębiorstwa, które zaangażowane są w alians dłużej niż 1 rok".

Dłuższa współpraca sprzyja wypracowaniu zgodności celów strategicznych i rozwijaniu innowacyjnych rozwiązań. Badania A. Sopińskiej i P. Dziurskiego (2018, s. 147-159) wykazały, że innowacyjne przedsiębiorstwa stosują jednak strategię zachowawczą, jeśli chodzi o współpracę z innymi podmiotami biznesowymi. Ł. Wściubiak (2019, s. 12-18) stwierdza natomiast, że „przedsiębiorstwa wykazujące wysoki poziom innowacyjności są zainteresowane nie tyle wykorzystaniem zewnętrznych partnerów jako źródła pomysłów czy gotowych rozwiązań, lecz raczej zaangażowaniem ich w prace nad już realizowanymi projektami, w celu doprowadzenia ich do pomyślnego finału". Chodzi więc bardziej o kompensowanie brakujących zasobów i kompetencji.

Należy wskazać, że prezentowane powyżej poglądy cytowanych autorów są całkowicie zasadne i stanowią podstawę (w części) sformułowania wniosków końcowych przez autora publikacji. 


\section{Bariery rozwoju innowacyjności w Polsce - wyniki badań własnych}

W latach 2011-2013 zespół badawczy UŁ kierowany przez J. Różańskiego oraz Instytut Innowacji Uniwersytetu w Manchesterze (jako podwykonawca) prowadziły równoległe badania (realizując grant strukturalny UE na lata 2011-2013) dotyczace problematyki innowacyjności przedsiębiorstw. Badania prowadzone przez zespół UŁ miały charakter ankietowy i objęły próbę 500 przedsiębiorstw mających swoją siedzibę w Łodzi i na terenie województwa łódzkiego. Operatem losowania był rejestr statystyczny REGON województwa łódzkiego według wybranych rodzajów działalności gospodarczej. Zastosowanie warstwowego systemu losowania związane było z podziałem przedsiębiorstw na dwie grupy: przedsiębiorstw przemysłowych i przedsiębiorstw usługowych (343 przedsiębiorstwa przemysłowe i 157 przedsiębiorstw usługowych). Materiał źródłowy został przygotowany przez grupę profesjonalnych ankieterów i poddany opracowaniu statystycznemu w programie IBM SPSS. Badaniami objęto wszystkie grupy przedsiębiorstw z punktu widzenia wielkości, a więc mikro, małe, średnie i duże przedsiębiorstwa.

Ograniczone ramy artykułu nie pozwalają na dokładne omówienie wszystkich wyników badań. Warto jednak wspomnieć, że badano wszystkie przejawy działalności innowacyjnej (innowacje produktowe, procesowe, organizacyjne, marketingowe), metody pozyskiwania innowacji, podstawowe wskaźniki mierzenia innowacyjności, przyczyny prowadzenia działalności innowacyjnej, źródła finansowania innowacji, bariery działalności innowacyjnej.

Analizy barier innowacyjności przeprowadzono w podziale na wszystkie grupy przedsiębiorstw z punktu widzenia ich wielkości, zakładając, że siła występowania poszczególnych barier w każdej z nich może być trochę inna.

Wyniki badań zawiera tabela 1 . Jak wynika $\mathrm{z}$ danych zawartych w tabeli, różnice w ocenie barier innowacyjności w poszczególnych grupach są bardzo niewielkie.

We wszystkich przypadkach najpoważniejszą barierą są wysokie koszty przygotowania i wdrażania innowacji, przy czym im mniejsze przedsiębiorstwo, tym znaczenie tej bariery wzrasta, co jest zrozumiałe. Z kolei brak wykwalifikowanego personelu wydaje się relatywnie większą barierą w dużych przedsiębiorstwach. Jeszcze dwa czynniki mogą być uznane za istotne:

- niewystarczająca baza techniczna;

- trudny dostęp do odpowiednich specjalistów i doradców;

przy czym $w$ tym ostatnim przypadku bariera ta jest uznana za dotkliwszą również $\mathrm{w}$ przypadku dużych przedsiębiorstw, które przecież powinny mieć łatwiejszy dostęp zarówno do bazy technicznej, jak i odpowiednich specjalistów i doradców grup.

\section{Doświadczenia wybranych krajów w zakresie wdrażania innowacji - wyniki badań Instytutu Innowacji Uniwersytetu w Manchesterze}

I nstytut Innowacji postanowił, po wcześniejszym rozpoznaniu specyfiki działań poszczególnych krajów w zakresie innowacyjności, przeprowadzić badania w Wielkiej Brytanii, Niemczech i Hiszpanii. Chodziło o to, aby porównać kraje o różnym podejściu do problematyki wdrażania innowacji i zbadać efekty każdego z trzech odmiennych podejść. Metodyka badań prowadzonych przez Instytut Innowacji nie została udostępniona polskiemu partnerowi. Wnioski płynące z tych badań opisano poniżej.

Jednym z krajów, w których innowacje są wdrażane w sposób bardzo konsekwentny, jest Wielka Brytania. Uczelnie brytyjskie od wielu lat są $\mathrm{w}$ znacznej mierze finansowane przez przedsiębiorstwa. Charakterystyczną cechą współpracy przedsiębiorstw brytyjskich ze sferą nauki jest wypracowany przez lata mechanizm, pozwalający na bardzo precyzyjne formułowanie oczekiwań przedsiębiorstw w stosunku do wyższych uczelni i jednostek otoczenia biznesu, co daje możliwość ukierunkowania badań naukowych tak, aby były one najbardziej przydatne dla przedsiębiorstw, często na ich konkretne zamówienia. Ale nie tylko biznes finansuje badania naukowe. Powstała w 1991 roku Rada Finansowania Szkolnictwa Wyższego finansuje podstawową działalność badawczą uczelni wyższych, często wspierając konkretne projekty badawcze (programy badań, które zostały wyłonione w drodze konkursowej). W skali lokalnej finansowaniem innowacji zajmuje się Fundusz Innowacyjności Szkolnictwa Wyższego (Uyarra i in., 2012, s. 5-8).

Tabela 1. Bariery działalności innowacyjnej w badanych przedsiębiorstwach

\begin{tabular}{|c|c|c|c|c|c|}
\hline Wyszczególnienie & Mikro & Małe & Średnie & Duże & Ogółem \\
\hline 1. Wysokie koszty przygotowania i wdrożenia innowacji & 84,8 & 81,8 & 79,7 & 77,3 & 82,0 \\
\hline 2. Brak odpowiednio wykwalifikowanego personelu & 23,8 & 30,4 & 32,8 & 45,5 & 29,9 \\
\hline 3. Niewystarczająca baza techniczna & 27,6 & 29,1 & 35,9 & 27,3 & 29,7 \\
\hline 4. Brak informacji na temat nowości technicznych & 21,9 & 17,0 & 12,5 & 13,6 & 17,4 \\
\hline 5. Brak znajomości rynku (potrzeb klientów, możliwości sprzedaży) & 7,6 & 7,3 & 12,5 & 4,5 & 8,0 \\
\hline 6. Trudny dostęp do odpowiednich specjalistów i doradców & 21,9 & 27,1 & 23,4 & 36,4 & 25,8 \\
\hline 7. Brak sektorowych kontaktów & 7,6 & 16,2 & 17,2 & 13,6 & 14,2 \\
\hline 8. Inne & 1,0 & 3,2 & 1,6 & - & 2,3 \\
\hline
\end{tabular}


Warto wspomnieć jeszcze o voucherze innowacyjnym, który ma na celu zachęcanie małych i średnich przedsiębiorstw do nawiązywania współpracy ze sferą nauki - jest to warunek uzyskania przez przedsiębiorstwa tego rodzaju wsparcia.

Ogółem, ponad 1/4 środków finansowych przeznaczonych na innowacje (finansowanie sfery $\mathrm{B}+\mathrm{R}$ ) stanowią środki asygnowane przez agendy rządowe, natomiast $61 \%$ nakładów na działalność $B+R$ pochodzi od przedsiębiorstw. Pozostałe środki są zapewnione $\mathrm{z}$ własnych funduszy uczelni i instytutów badawczych.

Bardzo istotną rolę spełniają w Wielkiej Brytanii jednostki otoczenia biznesu (parki naukowe, inkubatory przedsiębiorczości, biura transferu technologii), często usytuowane przy uczelniach wyższych.

Nieco inne rozwiązania przyjęto w Niemczech. Jest to kraj, który również jest uważany za jeden z najbardziej innowacyjnych krajów UE. Charakterystyczną cechą polityki innowacyjnej prowadzonej przez Niemcy jest to, że równolegle prowadzona jest na szczeblu centralnym (federalnym) i regionalnym (landów). Z małymi wahaniami w poszczególnych latach, około $20 \%$ wszystkich wydatków ponoszonych na sferę $\mathrm{B}+\mathrm{R}$ to wydatki ponoszone przez uczelnie wyższe, natomiast ok. $15 \%$ to wydatki stowarzyszeń naukowych i instytucji o charakterze doradczym. Za politykę naukową, ale również i politykę innowacyjną odpowiedzialne jest Ministerstwo Edukacji i Badań Naukowych oraz Ministerstwo Gospodarki i Technologii. Środki na badania przyznaje albo Niemiecka Fundacja Badawcza (w grupie badań podstawowych), albo agencje wdrożeniowe, najczęściej finansujące działalność badawczą w poszczególnych landach.

Podobnie jak w Wielkiej Brytanii, większość nakładów na działalność badawczo-rozwojową jest finansowanych przez przedsiębiorstwa (około 65\% średnio w poszczególnych latach) (Uyarra i in., 2012, s. 35-40). Należy dodać, że Niemcy mają bardzo dobrą infrastrukturę do prowadzenia badań zarówno podstawowych, jak i stosowanych. Jednocześnie niemiecki system finansowania innowacji jest uważany za bardzo elastyczny, pozwala skupiać się na tych innowacjach, które na poziomie całego kraju lub poszczególnych landów mogą być uznane za szczególnie istotne w danym momencie.

Krajem, który można porównać z Polską, biorąc pod uwagę obszar, liczbę ludności i stopień rozwoju gospodarki, jest Hiszpania. Dane uzyskane przez naukowców z Uniwersytetu w Manchesterze potwierdzają, że, podobnie jak w innych krajach, polityka innowacyjna prowadzona jest tu na szczeblach krajowym i regionalnym. Podstawą polityki w zakresie innowacji są czteroletnie plany krajowe, które określają zadania poszczególnych ministerstw. $\mathrm{Na}$ poziomie regionalnym powołano 17 wspólnot, mających własne autonomiczne regulacje, dotyczące wdrażania rozwiązań naukowych.

Niejasność podziału na obowiązki centralne i regionalne $\mathrm{w}$ dziedzinie prowadzenia polityki innowacyjnej sprawia, że efekty Hiszpanii nie są najlepsze - osiąga ona $\mathrm{z}$ trudnością średni europejski poziom. Korzystne jest natomiast pozostawienie relatywnie dużej części decyzji w regionach, co jak się okazało, sprzyja innowacyjności.
Dobrym przykładem jest tu wdrażanie systemu inteligentnych specjalizacji na Balearach.

Podobnie jak w Polsce, zdecydowaną przewagę w Hiszpanii mają małe i średnie przedsiębiorstwa, najczęściej działające $\mathrm{w}$ sektorach tradycyjnych, relatywnie mała jest liczba przedsiębiorstw działających w skali międzynarodowej, słabo rozwinięty sektor wysokich technologii. Badania naukowe $\mathrm{w}$ dużym stopniu rozmijają się $\mathrm{z}$ oczekiwaniami przedsiębiorstw, brakuje szerszego wsparcia dla małych i średnich przedsiębiorstw, które wykazują zainteresowania wdrażaniem innowacji, niedostatecznie rozbudowane są instytucje otoczenia biznesu (parki naukowe i technologiczne, inkubatory przedsiębiorczości) i ich rola jest zbyt marginesowa, jeśli chodzi o pomoc dla przedsiębiorstw, również w nawiązywaniu kontaktów z wyższymi uczelniami.

\section{Podsumowanie}

Wniki badań własnych zespołu UŁ, badania przeprowadzone przez Instytut Innowacji oraz poglądy cytowanych autorów wskazują na to, że:

Zdecydowanie najpoważniejszą barierą inicjowania i wdrażania innowacyjności są wysokie koszty przygotowania i wdrażania innowacji, zwłaszcza w małych przedsiębiorstwach, co wykazały badania własne prowadzone w przedsiębiorstwach regionu łódzkiego. Dlatego też grupa przedsiębiorstw sektora MSP powinna być objęta wsparciem finansowym na poziomie regionalnym przez jednostki samorządu terytorialnego w korelacji z oceną planowanych przez te przedsiębiorstwa innowacji.

Doświadczenia innych krajów wskazują, że konieczne jest bardzo precyzyjne formułowanie oczekiwań biznesu w stosunku do uczelni, instytutów badawczych i jednostek otoczenia biznesu. W oparciu o sformułowane przez biznes oczekiwania sfera nauki powinna kierunkować swoje prace badawcze tak, aby były jak najbardziej użyteczne dla biznesu. Istotną rolę powinny tu spełniać centralne lub regionalne elektroniczne platformy transferu wiedzy, będące miejscem zgłaszania zapotrzebowania na konkretne innowacje (produktowe, procesowe itd.) oraz lokowanie ofert służących rozwiązywaniu problemów przedsiębiorstw, zgłaszanych przez naukę. Przyczyni się to do uzyskania szerszego finansowania badań naukowych przez biznes (jak to ma miejsce w Wielkiej Brytanii i w Niemczech).

Potrzebne jest też precyzyjne rozgraniczenie uprawnień władz centralnych i regionalnych w sterowaniu polityką innowacyjną (negatywny przykład Hiszpanii). Finansowe wsparcie przedsiębiorstw płynące zarówno ze szczebla centralnego, jak i regionalnego powinno być powiązane $\mathrm{z}$ wieloaspektową oceną efektywności działania przedsiębiorstw, a zwłaszcza inwestycji przez nie podejmowanych, tak aby pieniądze mogły być jak najbardziej efektywnie wykorzystane. Wyeliminowano by w ten sposób przedsiębiorstwa, które wprawdzie potrzebują pieniędzy na innowacje, ale nie są w stanie ich efektywnie wykorzystać.

W warunkach istnienia niedostatecznego rozwoju sfery $\mathrm{B}+\mathrm{R}$ i niezbyt wysokiej nowoczesności gospodarki, nie należy lekceważyć korzyści płynących z zakupu gotowych rozwiązań oraz wprowadzania imitacji (doskonały wzorzec krajów azjatyckich). 
Całkowicie należy również zmienić system kierowania środków na innowacje, płynące z Unii Europejskiej. Cały czas system ten przyczynia się do marnowania środków unijnych. Należy premiować projekty ambitne, długofalowe i wyeliminować szkodliwy wpływ grup lobbystycznych, których w Polsce nie brakuje.

Jednostki otoczenia biznesu (parki przemysłowe i technologiczne, centra transferu technologii, inkubatory przedsiębiorczości) działają w Polsce zbyt słabo. Muszą one stać się nie pozornym, ale rzeczywistym elementem transmisji innowacji do przedsiębiorstw. W ich działalności wciąż jest zbyt dużo działalności biurokratycznej a nie działalności rzeczywistej.

W tej sytuacji konieczna jest ściślejsza współpraca przedsiębiorstw, w sferze inicjowania i wdrażania innowacji (alianse strategiczne, układy sieciowe), umożliwiająca nie tylko dokonanie wymiany doświadczeń, ale również wspólne finansowanie przedsięwzięć innowacyjnych. Należy wspierać finansowo takie alianse.

Innowacje powinny stać się podstawowym czynnikiem przebudowy struktury polskiej gospodarki. Chodzi tu o stopniowe, ewolucyjne odchodzenie od tradycyjnie mniej zyskownych i mniej konkurencyjnych sektorów gospodarki na rzecz bardziej nowoczesnych. Ta przebudowa struktury gospodarczej winna być wspierana zarówno na szczeblu centralnym (innowacje przełomowe), jak i regionalnym (innowacje pozostałe) jako element polityki gospodarczej.

Innowacje są prostą drogą do stworzenia konkurencyjnej gospodarki, w której wszyscy osiągną profity: państwo - bo więcej zyskownych przedsiębiorstw, to wyższe kwoty podatku, przedsiębiorstwa - bo wyższa konkurencyjność, również w skali międzynarodowej, pracownicy - bo wyższe zarobki, słabsze ekonomicznie grupy społeczeństwa - bo bogatsze państwo, o większych możliwościach wspierania grup zagrożonych wykluczeniem lub ubóstwem, ogół obywateli - bo większe nakłady na bezpieczeństwo obywateli i bezpieczeństwo państwa.

Należy wskazać, że przedstawione rekomendacje mają ograniczony zakres, wiążą się bowiem z problematyką występowania barier innowacyjności, a więc przede wszystkim $\mathrm{z}$ niedoskonałym mechanizmem jej finansowania. Dlatego też zostały pominięte inne, również zbadane i również istotne dla problemu innowacyjności przedsiębiorstw w Polsce zagadnienia, jak: rodzaje działań innowacyjnych, motywy przedsiębiorców podejmujących innowacje, metody pozyskiwania innowacji oraz ocena ich efektywności. Prezentacja wyników tych badań pozwoliłaby przedstawić bardziej kompleksowo problematykę innowacyjności w Polsce, ale nie jest to możliwe ze względu na pożądaną objętość artykułu.

Dalsze badania powinny się koncentrować na:

- ocenie dotychczasowego działania regionalnych platform transferu wiedzy i określeniu warunków ich prawidłowego funkcjonowania;

- ocenie dotychczasowego działania jednostek wspierających przedsiębiorstwa na szczeblu centralnym i regionalnym i opracowaniu bardziej precyzyjnych zasad ich działania - dotyczy to wszystkich jednostek otoczenia biznesu;

- tworzeniu systemu zachęt dla przedsiębiorstw, które wykazują wolę współpracy w dziedzinie wdrażania innowacji.

\author{
prof. dr hab. Jerzy Różański \\ Uniwersytet Łódzki \\ Wydział Zarządzania \\ ORCID: 0000-0003-3222-209X \\ e-mail: jerzy.rozanski@uni.lodz.pl
}

\section{Bibliografia}

[1] Brzóska J., Cierkosz J. (2016), Ocena innowacyjności przedsiębiorstw w Polsce, „Przegląd Organizacji”, Nr 10, s. 12-22.

[2] Cieślik J. (2014), Przedsiębiorczość, polityka, rozwój, Wyd. Akademickie Sedno, Warszawa.

[3] Cohen W.M., Levinthal D.A. (1989), Innovation and Learning: The Two Faces of $R \& D$, „The Economic Journal”, No. 99, pp. 569-596.

[4] Drewniak R. (2018), Innowacyjność przedsiębiorstw $w$ ramach aliansu strategicznego, „Organizacja i Kierowanie", $\mathrm{Nr} 4$, s. 151-167.

[5] European Innovation Scoreboard 2011-2019, doi: 10.2873./877069, access date: 29.11.2019.

[6] Kaźmierczak D., Różański J. (2013), Ocena barier we wdrażaniu innowacji $w$ przedsiębiorstwach regionu łódzkiego a ich wspótpraca $z$ ośrodkami naukowymi na tle istniejących rozwiązań w Wielkiej Brytanii, [w:] J. Różański (red.), Wspótpraca nauki i biznesu jako czynnik wzmacniajacy innowacyjność regionu łódzkiego, Wyd. Biblioteka, Łódź, s. 147-153.

[7] Matuszak M. (2008), Niedoceniane bariery rozwoju przedsiębiorczości i innowacyjności, [w:] E. Sadowska-Kowalska (red.), Przedsiębiorczość i innowacyjność $w$ Polsce $w$ kontekście europejskim - ocena dystansu, Fundacja Rozwoju Przedsiębiorczości, Łódź, s. 89-103.

[8] Rosati D., Wiśniewska J. (red.), (2016), Działalność innowacyjna przedsiębiorstw $w$ Polsce, CeDeWu, Warszawa.

[9] Różański J., Voytovych N. (2019), Transfer technologii $w$ procesach innowacyjnych przedsiębiorstw, Wydawnictwo Uniwersytetu Łódzkiego, Łódź.

[10] Sopińska A., Dziurski P. (2018), Strategia współpracy $w$ otwartych innowacjach $w$ Polsce, „Organizacja i Kierowanie", Nr 2, s. 147-159.

[11] Swacha J. (2016), Innowacyjność i konkurencyjność przedsiębiorstw polskiego sektora technologii informacyjnych na tle europejskich liderów, „Przegląd Organizacji”, Nr 1, s. 37-45.

[12] Wiśniewska J., Janasz K. (red.), (2016), Zarządzanie przedsiębiorstwem przemysłowym we współczesnej gospodarce, CeDeWu, Warszawa.

[13] Uyarra E., Kitagawa F., Almann K., Estevez J.G. (2012), Cooperation between the Scientific Environment and Enterprises in the United Kingdom, Manchester Institute of Innovation Research, Manchester Business School, University of Manchester.

[14] Wrzalik A., Kucęba R. (2019), Zarządzanie technologiami innowacyjnymi $i$ ich wdrażanie $w$ przedsiębiorstwach ciepłowniczych, „Przegląd Organizacji”, Nr 1, s. 27-35.

[15] Wściubiak Ł. (2019), Motywy współpracy międzyorganizacyjnej $w$ działalność innowacyjnej - perspektywa przedsiębiorstw produkcyjnych $w$ Polsce, „Przegląd Organizacji”, Nr 8, s. 12-18. 


\section{Innovation Support and Barriers to its Implementation - International Comparisons}

\section{Summary}

The innovation level of the economies of individual European Union member states (and associated countries - such as Norway and Switzerland) is very diverse. The Scandinavian countries, Germany and the United Kingdom show the highest innovation level, while the lowest is manifested by the majority of the new members of the European Union, including Poland. Therefore, it is important to identify the reasons why some countries have achieved a high level of innovation, and others - with this article focusing mainly on Poland - have not even managed to reach the European average.

The aim of the article is to make an attempt to provide the answer to this, based on available literature and the author's own research, as well as indication of activities that would allow Polish enterprises and the economy as a whole reach a higher innovation level and thus, higher competitiveness on global markets.

Effective activities of many countries in this area may be a model for others, including Poland.

The experiences of Poland, Great Britain, Germany, and Spain indicate that:

- it is necessary to precisely formulate business expectations in relation to universities, research institutes and business environment units, and sphere of science should direct its research work to make it as useful as possible for business;

- it is necessary to precisely delimit the powers of central and regional authorities in controlling the innovation policy.

\section{Keywords}

innovation support system, barriers of innovation, international comparisons 